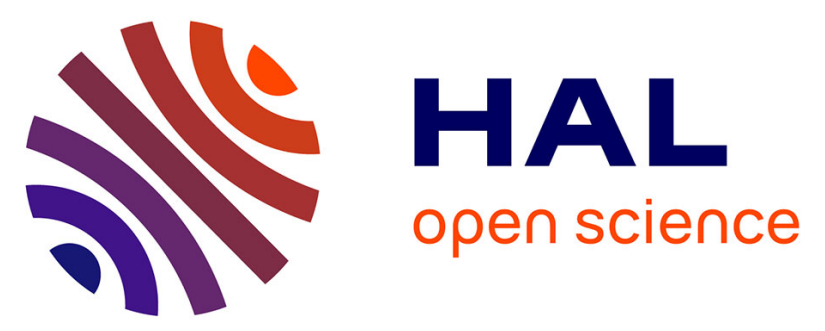

\title{
Change in Expression of 5-HT6 Receptor at Different Stages of Alzheimer's Disease: A Postmortem Study with the PET Radiopharmaceutical [18F]2FNQ1P
}

Pierre Courault, Stéphane Emery, Sandrine Bouvard, François Liger, Fabien Chauveau, David Meyronet, Anthony Fourier, Thierry Billard, Luc Zimmer, Sophie Lancelot

\section{To cite this version:}

Pierre Courault, Stéphane Emery, Sandrine Bouvard, François Liger, Fabien Chauveau, et al.. Change in Expression of 5-HT6 Receptor at Different Stages of Alzheimer's Disease: A Postmortem Study with the PET Radiopharmaceutical [18F]2FNQ1P. Journal of Alzheimer's Disease, 2020, 75 (4), pp.13291338. 10.3233/JAD-191278 . hal-03035778

\section{HAL Id: hal-03035778 https://hal.science/hal-03035778}

Submitted on 7 Dec 2020

HAL is a multi-disciplinary open access archive for the deposit and dissemination of scientific research documents, whether they are published or not. The documents may come from teaching and research institutions in France or abroad, or from public or private research centers.
L'archive ouverte pluridisciplinaire $\mathbf{H A L}$, est destinée au dépôt et à la diffusion de documents scientifiques de niveau recherche, publiés ou non, émanant des établissements d'enseignement et de recherche français ou étrangers, des laboratoires publics ou privés. 

A Postmortem Study with the PET
Radiopharmaceutical $\left[{ }^{18} \mathrm{~F}\right] 2 \mathrm{FNQ} 1 \mathrm{P}$

Pierre Courault $^{\mathrm{a}, \mathrm{b}}$, Stéphane Emery ${ }^{\mathrm{a}}$, Sandrine Bouvard $^{\mathrm{a}}$, François Liger $^{\mathrm{c}}$, Fabien Chauveau ${ }^{\mathrm{a}}$, David Meyronet $^{\mathrm{b}}$, Anthony Fourier ${ }^{\mathrm{a}, \mathrm{b}}$, Thierry Billard ${ }^{\mathrm{c}, \mathrm{d}}$, Luc Zimmer ${ }^{\mathrm{a}, \mathrm{b}, \mathrm{c}, \mathrm{e}, *}$ and Sophie Lancelot ${ }^{\mathrm{a}, \mathrm{b}, \mathrm{c}}$

${ }^{a}$ Lyon Neuroscience Research Center (CRNL), Université de Lyon, CNRS, INSERM, Lyon, France

${ }^{\mathrm{b}}$ Hospices Civils de Lyon (HCL), Lyon, France

${ }^{\mathrm{c} C E R M E P-I m a g i n g}$ platform, Groupement Hospitalier Est, Bron, France

${ }^{\mathrm{d}}$ Institute of Chemistry and Biochemistry (ICBMS), Université de Lyon, CNRS, Villeurbanne, France

${ }^{\mathrm{e}}$ National Institute for Nuclear Science and Technology (INSTN), CEA, Saclay, France

Accepted 6 April 2020

\begin{abstract}
.
Background: The 5- $\mathrm{HT}_{6}$ receptor is one of the most recently identified serotonin receptors in the central nervous system. Because of its role in memory and cognitive process, this receptor might be implicated in Alzheimer's disease (AD) and associated disorders.

Objective: The aim of this study was to investigate the binding of $\left[{ }^{18} \mathrm{~F}\right] 2 \mathrm{FNQ} 1 \mathrm{P}$, a new specific radiotracer of $5-\mathrm{HT}_{6}$ receptors, and to quantify $5-\mathrm{HT}_{6}$ receptor density in caudate nucleus in a population of patients with different AD stages.

Methods: Patients were classified according to the "ABC" NIA-AA classification. In vitro binding assays were performed in postmortem brain tissue from the healthy control (HC; $n=8)$ and severe AD ("High"; $n=8)$ groups. In vitro quantitative autoradiography was performed in human brain tissue (caudate nucleus) from patients with different stages of AD: HC $(n=15)$, "Low" ( $n=18)$, "Int" $(n=20)$, and "High" $(n=15)$.

Results: In vitro binding assays did not show significant differences for the $\mathrm{K}_{\mathrm{D}}$ and $\mathrm{B}_{\max }$ parameters between "High" and HC groups. In vitro quantitative autoradiography showed a significant difference between the "High" and HC groups $(p=0.0025)$. We also showed a progressive diminution in $\left[{ }^{18} \mathrm{~F}\right] 2 \mathrm{FNQ} 1 \mathrm{P}$ specific binding, which parallels $5-\mathrm{HT}_{6}$ receptors expression, according to increasing AD stage. Significant differences were observed between the HC group and all AD stages combined ("Low", "Intermediate", and "High") ( $p=0.011)$.

Conclusion: This study confirms the interest of investigating the role of 5-HT 6 receptors in AD and related disorders. $\left[{ }^{18} \mathrm{~F}\right] 2 \mathrm{FNQ} 1 \mathrm{P}$ demonstrated specific binding to $5-\mathrm{HT}_{6}$ receptors.
\end{abstract}

Keywords: 5- $\mathrm{HT}_{6}$ receptor, Alzheimer's disease, caudate nucleus, $\left[{ }^{18} \mathrm{~F}\right] 2 \mathrm{FNQ} 1 \mathrm{P}$, specific PET radiotracer

\section{INTRODUCTION}

*Correspondence to: Luc Zimmer, CERMEP, Groupement Hospitalier Est, 59 bd Pinel, 69677 Bron cedex, France. Tel.: +33(0) 0472688609 ; E-mail: zimmer@univ-lyon1.fr.
Serotonin is reported to have many neurological functions as a neurotransmitter, in the central nervous system but also in many other organ systems: 
cardiovascular, pulmonary, and genitourinary [1]. Serotonin receptor studies identified 7 sub-families of serotonin receptor, with many subtypes in each [2]. The $5-\mathrm{HT}_{6}$ receptor is one of the most recently identified, first in rat [3,4] and then in the human brain [5]. The 5-HT receptor family is involved in many physiological processes such as memory, learning, and food intake. Many studies also demonstrated roles in pathophysiological processes, including Alzheimer's disease (AD) [6-15].

The pathophysiology of AD involves several mechanisms, from formation of extracellular amyloid- $\beta$ plaques [16], to neurofibrillary tangles in the intracellular environment [17], and consecutive neuronal death and synapse loss, all leading to progressive cognitive decline [18]. While the molecule-candidates targeting aggregated proteins have so far been therapeutic failures, a new strategy has emerged in parallel, seeking to target neurotransmission systems more specifically, with the objective of improving the clinical semiology of cognitive decline. An immunohistochemistry study revealed a significant reduction in $5-\mathrm{HT}_{6}$ receptor density in cortical areas of AD patients [19], opening up the possibility of specific targeting of this receptor at an early stage of the disease. Several clinical studies evaluated $5-\mathrm{HT}_{6}$ receptor antagonists in phase I, II, or III clinical trials for the treatment of AD. Early results were mixed: a phase I study showed the antagonist PRX-07034 to be selective for $5-\mathrm{HT}_{6}$, improving short-term memory, while a phase II study reported no benefit of another antagonist (SAM-760) on measures of cognition and neuropsychiatric symptoms in AD patients [20]. Unfortunately, another phase III clinical trial failed, testing idalopirdine, a $5-\mathrm{HT}_{6}$ receptor antagonist originally developed for cognitive improvement in $\mathrm{AD}$ [21]. However, other $5-\mathrm{HT}_{6}$ receptor antagonist compounds are still being investigated [22], such as SUVN-502, currently in phase II trial [23]. Furthermore, $5-\mathrm{HT}_{6}$ receptor agonists have paradoxically also been shown to have cognitive enhancement properties [10], leaving this target in the race for symptomatic treatment of AD. Nevertheless, it has to be recognized that research concerning antagonists are more developed than agonists.

In this context, visualizing and quantifying $5-\mathrm{HT}_{6}$ receptors during the patient's lifetime through PET imaging would be a valuable contribution to understanding this therapeutic target. The development of a specific radiotracer for $5-\mathrm{HT}_{6}$ receptors seems necessary for better understanding of $5-\mathrm{HT}_{6}$ receptor mechanisms in $\mathrm{AD}$, classification of $\mathrm{AD}$ grades and long-term follow-up of patients treated with $5-\mathrm{HT}_{6}$ antagonists. Several radiotracers have been described in literature, but none stands out as specific for the $5-\mathrm{HT}_{6}$ receptor $[24,25]$. Our laboratory recently developed a new specific radiotracer for these receptors, $\left[{ }^{18} \mathrm{~F}\right] 2 \mathrm{FNQ} 1 \mathrm{P}$. A previous study described the synthesis of its precursor and its radiolabeling [26]. A recent pre-clinical study in non-human primates suggested that $\left[{ }^{18} \mathrm{~F}\right] 2 \mathrm{FNQ} 1 \mathrm{P}$ is a reliable PET radiotracer for visualization and quantification of $5-\mathrm{HT}_{6}$ receptors [27].

Regional distribution and associated neuronal or glial expression of 5- $\mathrm{HT}_{6}$ receptors were investigated on human postmortem tissue by both autoradiography with $\left[{ }^{125} \mathrm{I}\right] \mathrm{SB} 258585$ and immunohistochemistry $[28,29]$. These studies revealed high levels in the striatum, moderate levels in the hippocampus and cerebral cortex, and low levels in cerebellum.

The aim of the present study was to investigate postmortem binding of $\left[{ }^{18} \mathrm{~F}\right] 2 \mathrm{FNQ} 1 \mathrm{P}$ in the caudate nucleus in a population of patients at different $\mathrm{AD}$ stages. This region, rarely explored in the context of AD [16], was chosen because of its high density of $5-\mathrm{HT}_{6}$ receptors, favorable for quantitative autoradiographic analyses. We hypothesized that 5$\mathrm{HT}_{6}$ receptor density would correlate with the stage of $\mathrm{AD}$ progression and severity.

\section{MATERIALS AND METHODS}

\section{Subjects and tissue samples}

Adjacent unstained frozen slices $(30 \mu \mathrm{m}$ thickness) from human caudate nuclei $(n=68)$ were obtained from the London Neurodegenerative Diseases Brain Bank [30]. Sixteen fresh samples of caudate nucleus were also obtained: 10 from the 68 patients of the Medical Research Council (London) Neurodegenerative Diseases Brain Bank and 6 from the Medical Research Council (Lyon) bank (CardioBioTec, Lyon Hospitals) after approval by the hospital department review board. Patient ages, postmortem interval, and sex ratio were not significantly different $(p>0.05)$ between patient groups (Table 1). Tissues were collected through appropriate consent procedures under the ethics procedures of the brain banks. Patients were stratified according to the guidelines of the National Institute on Aging-Alzheimer's Association [31] This classification uses an "ABC" staging protocol for the 
Table 1

Demographic data of patients

\begin{tabular}{lcccc}
\hline AD Stages & HC & Low & Int & High \\
\hline Number of cases & 15 & 18 & 20 & 15 \\
Age (y) & $83.4 \pm 4.5$ & $86 \pm 4.1$ & $87.3 \pm 2.9$ & $83.1 \pm 4.2$ \\
Gender (M/F) & $6 / 9$ & $7 / 12$ & $15 / 5$ & $9 / 6$ \\
Postmortem interval (h) & $47.1 \pm 13.7$ & $47.8 \pm 8.9$ & $51.1 \pm 10.4$ & $46.2 \pm 13.9$ \\
\hline
\end{tabular}

No significant differences were observed between groups for age, sex ratio, and postmortem interval criteria $(p>0.05)$. HC, healthy control.

neuropathologic changes in $\mathrm{AD}$, based on three morphologic characteristics of the disease: amyloid- $\beta$ plaques (A), neurofibrillary tangles (B), and neuritic plaques (C). Using a system of scores for each group, the $\mathrm{ABC}$ score was transformed into four levels of $\mathrm{AD}$ neuropathologic alteration: $\mathrm{HC}$ (healthy control group), "Low", "Int" (intermediate), or "High".

For unstained frozen slices, 15 patients were in the "High" stage of AD, 20 "Int", 18 "Low", and 15 HC. For fresh caudate tissues, 8 patients were HC and 8 "High". The tissues were stored at $-80^{\circ} \mathrm{C}$ and defrosted extemporaneously.

\section{Radiosynthesis of the 5-HT6 receptor radiopharmaceutical and quality controls}

The chemical nitro-precursor of our $5-\mathrm{HT}_{6}$ PET radiotracer, $\left[{ }^{18} \mathrm{~F}\right] 2 \mathrm{FNQ} 1 \mathrm{P}$, was synthesized as described previously [26]. Radiolabeling with ${ }^{18} \mathrm{~F}$ was performed extemporaneously, on the days of the in vitro experiments, according to our published protocol [32]. Briefly, radiosynthesis used an automated Neptis fluorination module (OOC, Belgium). $\left[{ }^{18} \mathrm{~F}\right] 2 \mathrm{FNQ} 1 \mathrm{P}$ quality control determined radiochemical purity and molar activity on analytical HPLC assay at the end of each production run, guaranteeing the radiopharmaceutical quality of the radiotracer used for the following in vitro experiments: i.e., molar activity $>340 \mathrm{GBq} / \mu \mathrm{mol}$ and radiochemical purity $>98 \%$.

\section{In vitro binding assays}

In vitro binding assays were performed in postmortem fresh caudate nucleus samples from the HC and "High" groups. Briefly, tissues were preserved in phosphate buffered saline (PBS)/EDTA $0.1 \%$ and ground with buffer $(50 \mathrm{mM}$ Tris- $\mathrm{HCl} \mathrm{pH} 7.4$ at $25^{\circ} \mathrm{C}$ ) (BetaPrion, BSE Purification kit, HMOGEN TUB, biochemistry). Homogenates were centrifuged for $20 \mathrm{~min}$ at $35,000 \mathrm{~g}$ (Discovery M150 SE ultra- centrifuge, Hitachi). The pellet was resuspended in $50 \mathrm{mM}$ Tris- $\mathrm{HCl}\left(\mathrm{pH} 7.4\right.$ at $\left.25^{\circ} \mathrm{C}\right)$ and incubated for $15 \mathrm{~min}$ at $37^{\circ} \mathrm{C}$. Following two further centrifugation steps (as above), the membranes were finally resuspended and stored at $-80^{\circ} \mathrm{C}$ until use.

Brain tissues were preserved in buffer containing $50 \mathrm{mM}$ Tris- $\mathrm{HCl}, 10 \mu \mathrm{M}$ pargyline, $5 \mathrm{mM} \mathrm{MgCl}_{2}$, $5 \mathrm{mM}$ ascorbate, and $0.5 \mathrm{mM}$ EDTA (pH 7.4). Binding assay consisted of $50 \mu \mathrm{L}$ displacing compound (SB-258585 $1 \mu \mathrm{M}$ : a 5-HT 6 receptor antagonist) or buffer, $100 \mu \mathrm{L}$ membrane suspension (corresponding to approximately $60 \mu \mathrm{g}$ protein per well for brain tissue) and $50 \mu \mathrm{L}\left[{ }^{18} \mathrm{~F}\right] 2 \mathrm{FNQ} 1 \mathrm{P}$ (molar activity, 59.2 $\mathrm{GBq} / \mu \mathrm{mol}) .\left[{ }^{18} \mathrm{~F}\right] 2 \mathrm{FNQ} 1 \mathrm{P}$ was used at concentrations from 0.05 to $10 \mathrm{nM}$. Association rates were determined by incubation of membranes with radioligand at $25^{\circ} \mathrm{C}$ for $60 \mathrm{~min}$ before termination of the experiment. Bound radiolabeled tracer was separated from free tracer by filtration under reduced pressure (MultiScreen HTS-FB, Millipore). Filters were washed 6 times with $200 \mu$ L PBS. Washed filters were assayed for radioactivity by $\gamma$-counter (Gamma Wizard 2480, Perkin Elmer).

\section{Quantitative in vitro 5-HT $T_{6}$ receptor} autoradiography

In vitro autoradiography was performed on adjacent unstained frozen slices of human brain tissue (caudate nucleus) from patients with different stages of AD. For each patient, pairs of adjacent slices were defrosted. The first slide was incubated for $60 \mathrm{~min}$ in buffer containing $50 \mathrm{mM}$ Tris- $\mathrm{HCl}, 10 \mu \mathrm{M}$ pargyline, $5 \mathrm{mM} \mathrm{MgCl} 2,5 \mathrm{mM}$ ascorbate, and $0.5 \mathrm{mM}$ EDTA (pH 7.4) and $18.5 \mathrm{kBq} / \mathrm{mL}\left[{ }^{18} \mathrm{~F}\right] 2 \mathrm{FNQ} 1 \mathrm{P}$, to measure total binding, and the second was incubated in the same buffer with SB-258585 at a concentration of $100 \mathrm{nM}$, for the competition experiment to measure non-specific binding. Each slide contained two adjacent of caudate nucleus sections constituting duplicate for total and specific binding. After incubation, the slices were washed in distilled water, 
then dried and placed on a phosphor imaging plate (BAS-5000, Fujifilm) for $60 \mathrm{~min}$. The films were analyzed by a computer-assisted image analysis system (Multigauge, Fujifilm). For each patient, a regionof-interest (ROI) was manually drawn on one of the two sections of the slide to measure the total binding. This ROI was replicated on the other three sections (total binding and non-specific binding) to compare regions with a same size. These ROIs were positioned in homogeneous areas, avoiding folds or tissue damage due to poor sample quality, if any. The mean of total binding values and non-specific binding values (in PSM $/ \mathrm{mm}^{2}$ ) was calculated for each slide. Specific binding was determined by subtracting non-specific binding from total binding values.

In parallel, calibration standards were prepared from rat brain tissue homogenates, as described in a previous study [33]. Briefly, crushed rat brains were homogenized, and proteins were quantified by a chemical analyzer. The rest of the homogenates was frozen at $-80^{\circ} \mathrm{C}$. For each radiosynthesis, four homogenates were defrosted and mixed with increasing radioligand activities (116, 231, 463, and 925 $\mathrm{kBq})$. The mixture was then refrozen in isopentane

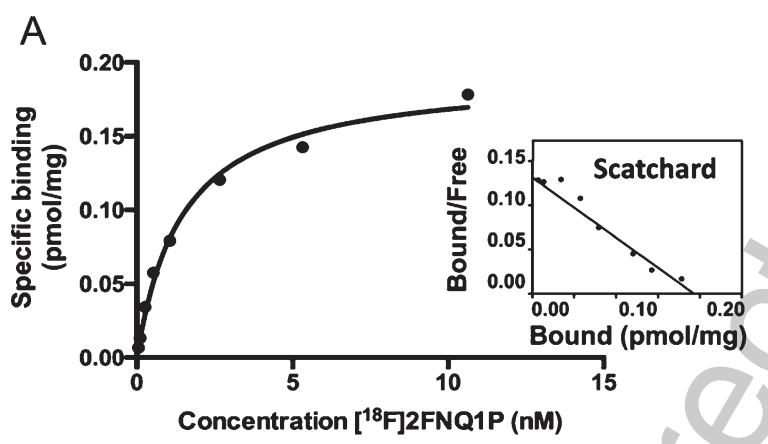

C

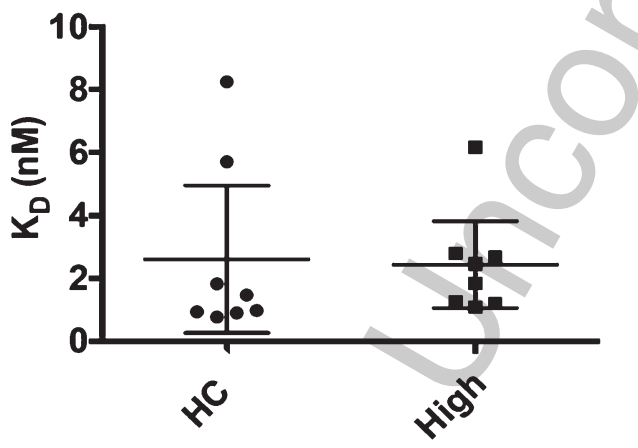

cooled with dry ice. The frozen samples were then cut into $30 \mu \mathrm{m}$ coronal slices using a $-20^{\circ} \mathrm{C}$ cryostat. The slices were placed on the human brain slices on the imaging plates and signal-to-concentration curves were calculated.

\section{Data analysis}

ANOVA tests assessed group homogeneity for age, gender, and postmortem caudate tissue sampling interval (Table 1).

In radioligand binding studies, $\mathrm{K}_{\mathrm{D}}$ and $\mathrm{B}_{\max }$ values were calculated using GraphPad Prism software (Graph Pad Software, Prism 6). Statistically significant variations in radioligand binding parameters were assessed on non-parametric Mann-Whitney test. For the quantitative autoradiography study, ANOVA assessed statistical differences. In case of a difference, results were compared between groups with on post-hoc Bonferroni correction test. Correlations between $\mathrm{AD}$ stages (quantified as: $\mathrm{HC}=0$; Low $=1$; Int $=2 ;$ High $=3$ ) and specific binding were assessed on Pearson's $\mathrm{r}$. For all analyses, the significance threshold was set at $p<0.05$.
B

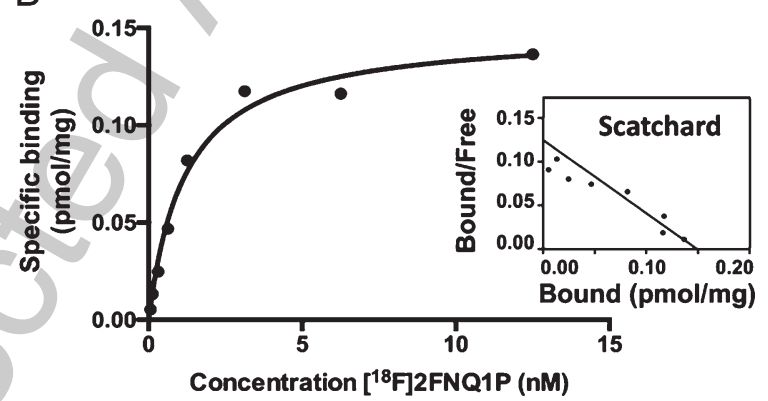

D

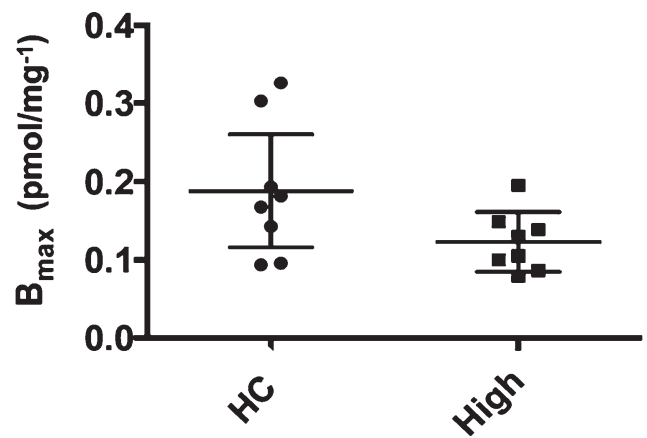

Fig. 1. In vitro binding assays. Example of saturation binding curves and Scatchard plots with fresh caudate nucleus samples from HC (A) and "High" AD stage (B) using the 5-HT 6 radiopharmaceutical $\left[{ }^{18} \mathrm{~F}\right] 2 \mathrm{FNQ} 1 \mathrm{P}$. No significant differences were observed between HC and "High" groups for the dissociation constant $\left(\mathrm{K}_{\mathrm{D}}\right)(\mathrm{C})$ or number of binding sites $\left(\mathrm{B}_{\max }\right)(\mathrm{D}$; Mann-Whitney test, $p>0.05)$. Bars plot mean and $95 \%$ confidence interval. 


\section{RESULTS}

In vitro binding assays

In vitro binding assay showed reproducible binding of $\left[{ }^{18} \mathrm{~F}\right] 2 \mathrm{FNQ} 1 \mathrm{P}$ to $5-\mathrm{HT}_{6}$ receptors in the $\mathrm{HC}$ and "High" groups (Fig. 1A, B). Mean radioligand equilibrium dissociation constants $\left(\mathrm{K}_{\mathrm{D}}\right)$ were $2.6 \pm 2.8$ $\mathrm{nM}$ and $2.4 \pm 1.7 \mathrm{nM}$ the $\mathrm{HC}$ group and "High" groups, respectively (Fig. 1C). Total $5-\mathrm{HT}_{6}$ receptor density $\left(\mathrm{B}_{\max }\right)$ was $0.19 \pm 0.09$ and $0.12 \pm 0.04$ for the HC group and "High" groups, respectively, the difference being non-significant (Fig. 1D).

\section{In vitro quantitative $5-\mathrm{HT}_{6}$ receptor autoradiography}

Regardless AD stage, all samples showed binding for $\left[{ }^{18} \mathrm{~F}\right] 2 \mathrm{FNQ} 1 \mathrm{P}$ according to the location of the $5-\mathrm{HT}_{6}$ receptor in the caudate nucleus. Figure $2 \mathrm{~A}$ represents an example of the total and non-specific binding of the $\left[{ }^{18} \mathrm{~F}\right] 2 \mathrm{FNQ} 1 \mathrm{P}$ depending on the stage of $\mathrm{AD}$. Mean percentage specific binding compared to total binding was respectively $21.1 \pm 9.7,16.9 \pm 15.3,16.5 \pm 12.6$, and $10.9 \pm 15.4$ for HC group, "Low", "Int", and "High" stages. Results are presented in Fig. 2 according to AD stage. Mean specific binding was respectively $96.1 \pm 27.6$, $68.4 \pm 41.4,70.9 \pm 48.7$, and $39.3 \pm 43.5 \mathrm{pmol} / \mathrm{mg}$ of protein for HC group, "Low", "Int", and "High" stages. ANOVA showed a significant difference between groups $(p=0.004)$. Post-hoc Bonferroni correction revealed a significant difference between the "High" and HC groups ( $p=0.0025)$ (Fig. 2B). Post-hoc tests did not reveal significant differences between HC, "Low", and "Int" groups, but specific binding showed a strong negative correlation with all stages from HC to "High" $(r=-0.42, p<0.01)$. A significant difference $(p=0.011)$ was also found between $\mathrm{HC}$ group and all $\mathrm{AD}$ stages combined ("Low", "Int", and "High") on post-hoc t-test with Bonferroni correction (Fig. 2C).

\section{DISCUSSION}

To our knowledge this is the first study investigating a specific PET radiotracer of 5- $\mathrm{HT}_{6}$ receptors in a population of $\mathrm{AD}$ patients with different stages of disease. The results showed a decrease in caudate 5$\mathrm{HT}_{6}$ receptor density with $\left[{ }^{18} \mathrm{~F}\right] 2 \mathrm{FNQ} 1 \mathrm{P}$ in subjects with $\mathrm{AD}$ compared to control group.
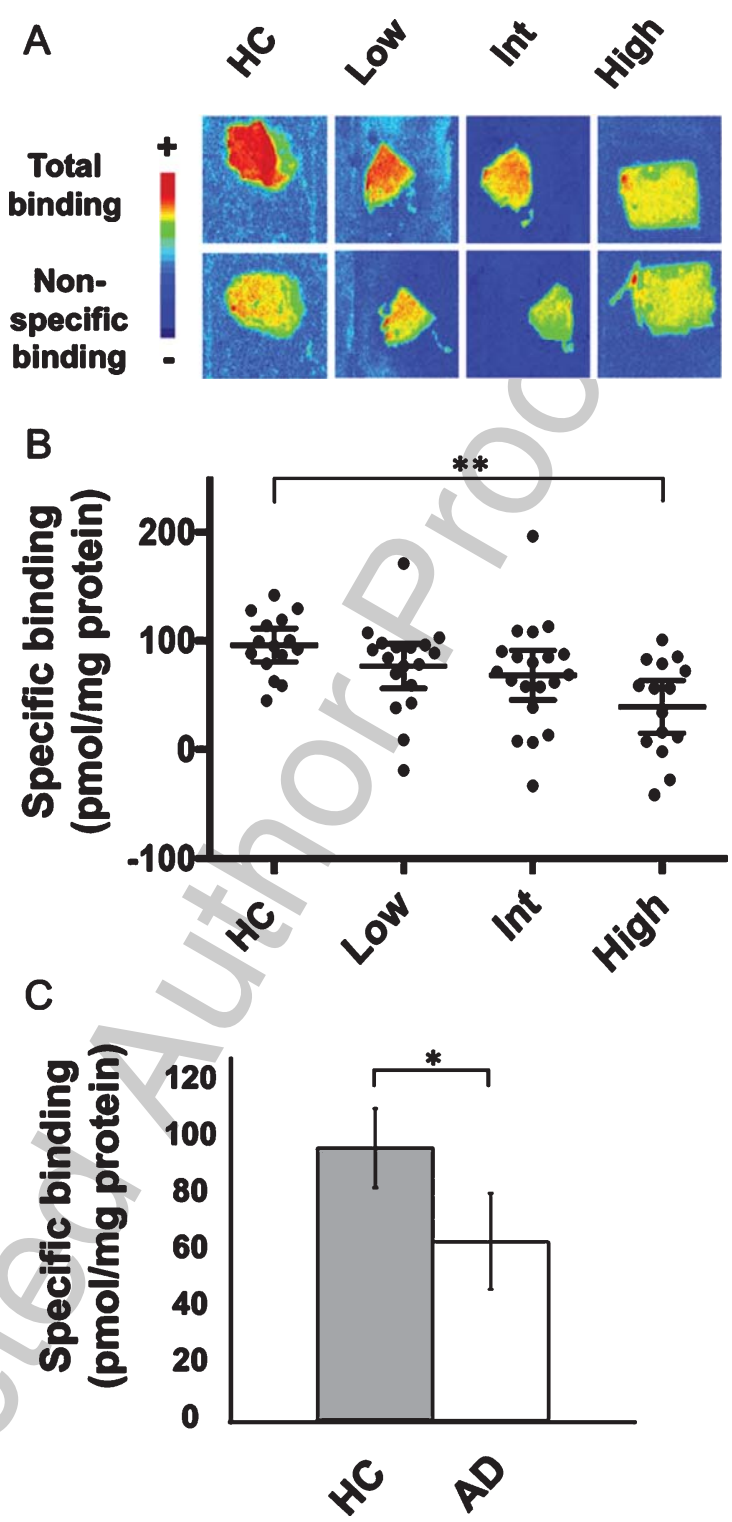

Fig. 2. Autoradiographic quantification of specific binding of the 5 - $\mathrm{HT}_{6}$ radiopharmaceutical $\left[{ }^{18} \mathrm{~F}\right] 2 \mathrm{FNQ} 1 \mathrm{P}$ according to group of patients. A) Example of regional distribution of $\left[{ }^{18} \mathrm{~F}\right] 2 \mathrm{FNQ} 1 \mathrm{P}$ binding sites in the caudate nucleus in $\mathrm{HC}$ and patient groups. The autoradiographs showing the decrease of $\left[{ }^{18} \mathrm{~F}\right] \mathrm{F} 2 \mathrm{FNQ} 1 \mathrm{P}$ binding when SB258585 is added during incubation represent non-specific binding. B) A significant difference was seen between the "High" and $\mathrm{HC}$ groups $(* * p<0.01)$. Bars plot mean and $95 \%$ confidence interval. C) A significant difference was also found between $\mathrm{HC}$ group and all AD stages combined ("Low", "Int" and "High") on post-hoc $t$-test with Bonferroni correction $(* p<0.05)$. Error-bars with $95 \%$ confidence intervals of the means do not overlap.

As previously outlined, $\left[{ }^{18} \mathrm{~F}\right] 2 \mathrm{FNQ} 1 \mathrm{P}$ is the only PET radiopharmaceutical currently available that is specific for $5-\mathrm{HT}_{6}$ receptors [32]. In addition, $\left[{ }^{18} \mathrm{~F}\right] 2 \mathrm{FNQ} 1 \mathrm{P}$ has a high specificity for $5-\mathrm{HT}_{6}$ 
receptors with comparison to the following serotoninergic receptors, 5- $\mathrm{HT}_{2 \mathrm{~A}}, 5-\mathrm{HT}_{2 \mathrm{~B}}, 5-\mathrm{HT}_{2} \mathrm{C}, 5-\mathrm{HT}_{1 \mathrm{~B}}$, $5-\mathrm{HT}_{4}$, as well as for dopamine $\left(\mathrm{D}_{2}, \mathrm{D}_{3}\right)$ and muscarinic $\left(\alpha_{1 \mathrm{~B}}\right)$ receptors, which are very present in the striatal regions [26]. In this study, binding assays showed reliable affinity of $\left[{ }^{18} \mathrm{~F}\right] 2 \mathrm{FNQ} 1 \mathrm{P}$ for these receptors. Radioligand saturation binding assays found no significant difference between the $\mathrm{HC}$ and "High" groups on the $\mathrm{K}_{\mathrm{D}}$ and the $\mathrm{B}_{\max }$ parameters. The high affinity of $\left[{ }^{18} \mathrm{~F}\right] 2 \mathrm{FNQ} 1 \mathrm{P}$ for $5-\mathrm{HT}_{6}$ was confirmed by the mean $\mathrm{K}_{\mathrm{D}}$ for each group (around $2.5 \mathrm{nM}$ ). This result is consistent with a previous study which found a $K_{D}$ of approximatively $1 \mathrm{nM}$ [26]. Although $B_{\max }$ was lower in the "High" than the HC group, the difference was non-significant. These results could be explained by the small size of the study population $(n=8)$. This explanation is frequently put forward in postmortem studies, as access to brains of neuropathologically documented $\mathrm{AD}$ subjects is limited. However, further investigations with a larger sample might demonstrate a significant difference, such as was found in the autoradiography assay.

Quantitative autoradiography experiments showed that $\left[{ }^{18} \mathrm{~F}\right] 2 \mathrm{FNQ} 1 \mathrm{P}$ was suitable for visualizing and quantifying striatal $5-\mathrm{HT}_{6}$ receptor density. In vitro competition assays with the $5-\mathrm{HT}_{6}$ antagonist SB258585 showed displacement of the radiotracer, confirming binding reversibility. Quantification of $5-\mathrm{HT}_{6}$ receptors revealed significant differences between the healthy control group (i.e., patients without $\mathrm{AD}$ neuropathological modifications) and patients with a high level of neuropathological modification ("High"). The results also distinguished the healthy control group from all AD stages. On the other hand, no significant differences were observed between the HC or "High" groups and other stages of AD ("Low" and "Int"). Despite these non-significant differences, the results showed a progressive decrease in the $5-\mathrm{HT}_{6}$ receptor expression according to $\mathrm{AD}$ stage, with a strong negative correlation between specific binding of $\left[{ }^{18} \mathrm{~F}\right] 2 \mathrm{FNQ} 1 \mathrm{P}$ and disease stage. Here again, the absence of significant difference between the "High" group and earlier stages of AD can be initially explained by the relatively low number of patients in each group. Larger groups would reinforce the power of the study and could demonstrate significant differences. Another explanation concerns the complexity of assessing AD. Because of the large inter-individual variability found in $\mathrm{AD}$, classification can be difficult. This is why many classifications exist, drawn up by different working groups such as the IWG-2 classification of the International Working Group for New Research Criteria for the Diagnosis of Alzheimer's Disease [34] and, more recently, the "ABC" classification of the National Institute of Aging-Alzheimer's Association (NIA-AA) [31], used in the present study. This classification considers $\mathrm{AD}$ as a continuum, needing to be diagnosed in its early stages. However, these criteria remain to be validated. Lowe et al. applied this classification to the Alzheimer Disease Neuroimaging Initiative (ADNI) cohort [35]. The study showed the weakness of the NIA-AA criteria because of the complexity of interpreting biomarkers. Other studies assessing the applicability of this classification in AD patients with mild cognitive impairment showed the same weakness: variability in biomarker interpretation, lack of measurement standardization, and varying results $[36,37]$. Furthermore, the "ABC" staging is strongly nested in other diseases contributing to cognitive impairment, such as Lewy body disease, vascular brain injury, or hippocampal sclerosis [38]. Thus, patient groups are difficult to distinguish, making it difficult to show significant differences between neighboring groups.

In addition, "ABC" staging is mostly based on anatomopathological criteria. The classification takes account of onset of $\mathrm{A} \beta$ or amyloid plaques, neurofibrillary tangles, and neuritic plaques, but not of clinical status. However, it is well known that anatomopathological modifications in $\mathrm{AD}$ correlate with disease symptomatology. Symptom onset correlates with brain atrophy [39], hypometabolism [40], and neurofibrillary changes [41]. Thus, the correlation between decreased 5-HT-6 receptor density and decrease in symptomatology could be an approach worth considering in future studies.

Another point to be taken into account in interpreting the present results concerns the polymorphism of the $5-\mathrm{HT}_{6}$ receptor. The human $5-\mathrm{HT}_{6}$ receptor protein is coded by chromosome 1 and the specific gene of the receptor contains many trinucleotide polymorphisms [5]. Some previous studies, in Chinese and Korean populations, showed an association between this polymorphism and $\mathrm{AD}$, and considered this allele to be a risk factor $[42,43]$. Another study, in a Caucasian population, found no significant differences between controls and AD patients [44], and considered this $5-\mathrm{HT}_{6}$ receptor polymorphism as a silent mutation that does not affect the function of the protein. To date, an association between $5-\mathrm{HT}_{6}$ polymorphism in $\mathrm{AD}$ patients and the binding properties of $\left[{ }^{18} \mathrm{~F}\right] 2 \mathrm{FNQ} 1 \mathrm{P}$ is still an open question. 
Although the present study is the first to visualize $5-\mathrm{HT}_{6}$ receptors in $\mathrm{AD}$ patients with a radiopharmaceutical usable for neuroimaging in vivo, a few previous studies also showed a decrease in these receptors in $\mathrm{AD}$ and related disorders, using dedicated in vitro exploration probes. Lorke et al., in an immunohistochemistry study [45], reported decreased cellular expression of $5-\mathrm{HT}_{6}$ receptors in the prefrontal cortex of $\mathrm{AD}$ patients in comparison with normal age-matched subjects. $5-\mathrm{HT}_{6}$ receptors were expressed in pyramidal cells and stellate-shaped cells, and $\mathrm{AD}$ patients showed a significant $40 \%$ decrease in $5-\mathrm{HT}_{6}$ receptor expression. Garcia-Alloza et al. reported similar results. They assessed the involvement of serotoninergic disturbance of $5-\mathrm{HT}_{6}$ receptors in $\mathrm{AD}$ impairment. Binding assays with $\left[{ }^{125} \mathrm{I}\right] \mathrm{SB}-258585$, an in vitro radiotracer, were performed on tissue samples from frontal and temporal cortex. Results showed a significant decrease in 5- $\mathrm{HT}_{6}$ receptor density in both frontal (56\% reduction) and temporal (58\% reduction) cortex in AD patients compared to controls [19]. While these results were consistent with $5-\mathrm{HT}_{6}$ receptor involvement in $\mathrm{AD}$, the authors did not use the clinicopathologic diagnostic classification used in the present study.

The present study also differs from a majority of previous studies in the choice of the brain region of interest: the caudate nucleus, well-known to be a region rich in 5- $\mathrm{HT}_{6}$ receptors [46, 47]. It is known that $5-\mathrm{HT}_{6}$ receptors are highly and homogeneously concentrated in the caudate nucleus, putamen, and nucleus accumbens [29]. The first preclinical explorations of our radiopharmaceutical confirmed its preferential striatal binding [26, 27, 32], justifying the choice of this region for the present postmortem study. However, it must be recognized that the pathophysiological involvement of the caudate nucleus in $\mathrm{AD}$ is not yet well established. Brain atrophy and neuron loss occurs mainly in the frontal cortex, hippocampus, and limbic areas [48]. De Jong et al. suggested a distinction in striatal pattern morphology in $\mathrm{AD}$ patients compared to subjects with memory complaints without objective cognitive impairment [49]. Their study showed that cognitive impairment is related to the degree of surface deformity, hypothesizing that associative and limbic cerebral networks are primarily affected in AD. These findings highlight the interest of tracing the progression of $5-\mathrm{HT}_{6}$ receptors as striatal marker during neurodegeneration.

This is all the more interesting as the 5- $\mathrm{HT}_{6}$ receptor is also a potential therapeutic target in $\mathrm{AD}$ [50].
Recently, drug-candidates have been developed on the pharmacological hypothesis that $5-\mathrm{HT}_{6}$ receptor blockade induces acetylcholine release and so improves cognition processes in AD [51]. So far, clinical studies were disappointing. Idalopirdine, a 5- $\mathrm{HT}_{6}$ receptor antagonist, did not improve cognition in patients with mild to moderate $\mathrm{AD}$ compared to placebo [21]; intepirdine, another selective $5-\mathrm{HT}_{6}$ receptor antagonist, did not show efficacy in a phase II study [52]. However, these early studies do not signify the abandonment of therapeutic targeting of $5-\mathrm{HT}_{6}$ receptors. Their main limitations were the lack of knowledge of 5- $\mathrm{HT}_{6}$ receptor status in groups of heterogeneous $\mathrm{AD}$ patients. The difficulty of staging patients may have led to underdosing in phase III compared to phase II [53]. It is therefore crucial to have better knowledge of the progression of $5-\mathrm{HT}_{6}$ receptors during the course of $\mathrm{AD}$, through PET imaging, to highlight potential early biomarkers, to refine the recruitment for future therapeutic trials, and, finally, to contribute to the understanding of 5- $\mathrm{HT}_{6}$ drug-candidates by drug occupancy studies. The translational results we obtained with the radiopharmaceutical $\left[{ }^{18} \mathrm{~F}\right] 2 \mathrm{FNQ} 1 \mathrm{P}$ therefore encourage us to implement a PET neuroimaging study in AD patients. Indeed, this in vivo exploration will enable us to quantify other brain regions expressing significant densities of 5- $\mathrm{HT}_{6}$ receptors relevant to $\mathrm{AD}$, such as the entorhinal, parietal, or frontal cortex, and to explore the modification of their expression during the disease progression.

\section{CONCLUSION}

This in vitro study is the first to demonstrate a decrease in caudate 5- $\mathrm{HT}_{6}$ receptor density with $\left[{ }^{18} \mathrm{~F}\right] 2 \mathrm{FNQ} 1 \mathrm{P}$, a PET radiopharmaceutical, in subjects with $\mathrm{AD}$. The challenge will now be to transfer $\left[{ }^{18} \mathrm{~F}\right] 2 \mathrm{FNQ} 1 \mathrm{P}$ to in vivo PET neuroimaging studies to confirm an early decline in $5-\mathrm{HT}_{6}$ receptor expression during disease progression and provide better understanding of the pharmacology of future candidate molecules targeting this serotoninergic receptor.

\section{ETHICS APPROVAL AND CONSENT TO PARTICIPATE}

Tissues were collected through appropriate consent procedures under the ethics procedures of the brain banks. Previous consent to do experiments 
was given at the time of brain donation, and no supplementary consent was needed for this study. The study was conducted according to the principles of the Helsinki and subsequent revisions.

\section{ACKNOWLEDGMENTS}

This study was performed under the LABEX PRIMES (ANR-11-LABX-0063) of Lyon University, within the "Investissements d'Avenir" program (ANR-11-IDEX-0007) operated by the French National Research Agency (ANR).

We particularly thank the CERMEP Imaging Platform team (Radiopharmacy-Radiochemistry Department) for technical assistance.

This study was supported by the French Alzheimer Foundation (Fondation Alzheimer, France).

Authors' disclosures available online (https:// www.j-alz.com/manuscript-disclosures/19-1278r2).

\section{AVAILABILITY OF DATA AND MATERIALS}

The data sets supporting the conclusions of this article can be made available upon request through the corresponding author.

\section{REFERENCES}

[1] Roth BL (2006) The Serotonin Receptors: From Molecular Pharmacology to Human Therapeutics, Humana Press, Totowa, NJ.

[2] Siegel GJ, Agranoff BW, Albers RW, Fisher SK, Uhler MD (1999) Basic Neurochemistry, Lippincott-Raven, Philadelpha.

[3] Monsma FJ, Shen Y, Ward RP, Hamblin MW, Sibley DR (1993) Cloning and expression of a novel serotonin receptor with high affinity for tricyclic psychotropic drugs. $\mathrm{Mol}$ Pharmacol 43, 320-327.

[4] Ruat M, Traiffort E, Arrang JM, Tardivel-Lacombe J, Diaz J, Leurs R, Schwartz JC (1993) A novel rat serotonin (5-HT6) receptor: Molecular cloning, localization and stimulation of cAMP accumulation. Biochem Biophys Res Commun 193, 268-276.

[5] Kohen R, Metcalf MA, Khan N, Druck T, Huebner K, Lachowicz JE, Meltzer HY, Sibley DR, Roth BL, Hamblin MW (1996) Cloning, characterization, and chromosomal localization of a human 5-HT6 serotonin receptor. $\mathrm{J} \mathrm{Neu}$ rochem 66, 47-56.

[6] D. R, J. H (2001) 5-HT 6 receptor antagonists enhance retention of a water maze task in the rat. Psychopharmacology (Berl) 158, 114-119.

[7] Woolley ML, Marsden CA, Fone KCF (2004) 5-ht6 receptors. Curr Drug Targets CNS Neurol Disord 3, 59-79.

[8] Perez-García G, Meneses A (2005) Oral administration of the 5-HT6 receptor antagonists SB-357134 and SB-399885 improves memory formation in an autoshaping learning task. Pharmacol Biochem Behav 81, 673-682.

[9] Claeysen S, Bockaert J, Giannoni P (2015) Serotonin: A new hope in Alzheimer's disease? ACS Chem Neurosci 6 , 940-943.

[10] Karila D, Freret T, Bouet V, Boulouard M, Dallemagne P, Rochais C (2015) Therapeutic potential of 5-HT6 receptor agonists. J Med Chem 58, 7901-7912.

[11] Sun B-L, Li W-W, Zhu C, Jin W-S, Zeng F, Liu Y-H, Bu X-L, Zhu J, Yao X-Q, Wang Y-J (2018) Clinical research on Alzheimer's disease: Progress and perspectives. Neurosci Bull 34, 1111-1118.

[12] de Jong IEM, Mørk A (2017) Antagonism of the 5HT6 receptor - Preclinical rationale for the treatment of Alzheimer's disease. Neuropharmacology 125, 50-63.

[13] Khoury R, Grysman N, Gold J, Patel K, Grossberg GT (2018) The role of 5 HT6-receptor antagonists in Alzheimer's disease: An update. Expert Opin Investig Drugs 27, 523-533.

[14] Bokare AM, Bhonde M, Goel R, Nayak Y (2018) 5-HT6 receptor agonist and antagonist modulates ICV-STZinduced memory impairment in rats. Psychopharmacology (Berl) 235, 1557-1570.

[15] Shahidi S, Hashemi-Firouzi N, Asl SS, Komaki A (2019) Serotonin type 6 receptor antagonist attenuates the impairment of long-term potentiation and memory induced by Abeta. Behav Brain Res 364, 205-212.

[16] Hardy J, Allsop D (1991) Amyloid deposition as the central event in the aetiology of Alzheimer's disease. Trends Pharmacol Sci 12, 383-388.

[17] Arriagada PV, Growdon JH, Hedley-Whyte ET, Hyman BT (1992) Neurofibrillary tangles but not senile plaques parallel duration and severity of Alzheimer's disease. Neurology $\mathbf{4 2}$, 631-639.

[18] Burns A, Iliffe S (2009) Alzheimer's disease. BMJ 338, b158.

[19] Garcia-Alloza M, Hirst WD, Chen CPL-H, Lasheras B, Francis PT, Ramírez MJ (2004) Differential involvement of 5-HT(1B/1D) and 5-HT6 receptors in cognitive and non-cognitive symptoms in Alzheimer's disease. Neuropsychopharmacology 29, 410-416.

[20] Fullerton T, Binneman B, David W, Delnomdedieu M, Kupiec J, Lockwood P, Mancuso J, Miceli J, Bell J (2018) A Phase 2 clinical trial of PF-05212377 (SAM-760) in subjects with mild to moderate Alzheimer's disease with existing neuropsychiatric symptoms on a stable daily dose of donepezil. Alzheimers Res Ther 10, 38.

[21] Atri A, Frölich L, Ballard C, Tariot PN, Molinuevo JL, Boneva N, Windfeld K, Raket LL, Cummings JL (2018) Effect of idalopirdine as adjunct to cholinesterase inhibitors on change in cognition in patients with Alzheimer disease: Three randomized clinical trials. JAMA $\mathbf{3 1 9}$, 130-142.

[22] Benhamú B, Martín-Fontecha $M$, Vázquez-Villa $H$, Pardo L, López-Rodríguez ML (2014) Serotonin 5-HT6 receptor antagonists for the treatment of cognitive deficiency in Alzheimer's disease. J Med Chem 57, 71607181.

[23] Nirogi R, Abraham R, Benade V, Medapati RB, Jayarajan P, Bhyrapuneni G, Muddana N, Mekala VR, Subramanian R, Shinde A, Kambhampati R, Jasti V (2019) SUVN-502, a novel, potent, pure, and orally active 5HT6 receptor antagonist: Pharmacological, behavioral, and neurochemical characterization. Behav Pharmacol 30, 16-35. 
[24] Parker CA, Gunn RN, Rabiner EA, Slifstein M, Comley R, Salinas C, Johnson CN, Jakobsen S, Houle S, Laruelle M, Cunningham VJ, Martarello L (2012) Radiosynthesis and characterization of 11C-GSK215083 as a PET radioligand for the 5-HT6 receptor. J Nucl Med 53, 295-303.

[25] Tang S, Verdurand M, Joseph B, Lemoine L, Daoust A, Billard T, Fournet G, Le Bars D, Zimmer L (2007) Synthesis and biological evaluation in rat and cat of [18F]12ST05 as a potential 5-HT6 PET radioligand. Nucl Med Biol 34, 995-1002.

[26] Colomb J, Becker G, Fieux S, Zimmer L, Billard T (2014) Syntheses, radiolabelings, and in vitro evaluations of fluorinated PET radioligands of 5-HT6 serotoninergic receptors. J Med Chem 57, 3884-3890.

[27] Sgambato-Faure V, Billard T, Météreau E, Duperrier S, Fieux S, Costes N, Tremblay L, Zimmer L (2017) Characterization and reliability of [18F]2FNQ1P in cynomolgus monkeys as a PET radiotracer for serotonin 5-HT6 receptors. Front Pharmacol 8, 471.

[28] Marazziti D, Baroni S, Pirone A, Giannaccini G, Betti L, Testa G, Schmid L, Palego L, Borsini F, Bordi F, Piano I, Gargini C, Castagna M, Catena-Dell'osso M, Lucacchini A (2013) Serotonin receptor of type 6 (5-HT6) in human prefrontal cortex and hippocampus post-mortem: An immunohistochemical and immunofluorescence study. Neurochem Int 62, 182-188.

[29] Marazziti D, Baroni S, Pirone A, Giannaccini G, Betti L, Schmid L, Vatteroni E, Palego L, Borsini F, Bordi F, Piano I, Gargini C, Castagna M, Catena-Dell'osso M, Lucacchini A (2012) Distribution of serotonin receptor of type $6\left(5-\mathrm{HT}_{6}\right)$ in human brain post-mortem. A pharmacology, autoradiography and immunohistochemistry study. Neurochem Res 37, 920-927.

[30] MRC London Neurodegenerative Diseases Brain Bank; MRC UK Brain Banks Network; https://www.kcl.ac. uk/ioppn/depts/bcn/our-research/neurodegeneration/brainbank.

[31] Hyman BT, Phelps CH, Beach TG, Bigio EH, Cairns NJ, Carrillo MC, Dickson DW, Duyckaerts C, Frosch MP, Masliah E, Mirra SS, Nelson PT, Schneider JA, Thal DR, Thies B, Trojanowski JQ, Vinters HV, Montine TJ (2012) National Institute on Aging-Alzheimer's Association guidelines for the neuropathologic assessment of Alzheimer's disease. Alzheimers Dement 8, 1-13.

[32] Becker G, Colomb J, Sgambato-Faure V, Tremblay L, Billard T, Zimmer L (2015) Preclinical evaluation of [18F]2FNQ1P as the first fluorinated serotonin 5-HT6 radioligand for PET imaging. Eur J Nucl Med Mol Imaging 42, 495-502.

[33] Vidal B, Sebti J, Verdurand M, Fieux S, Billard T, Streichenberger N, Troakes C, Newman-Tancredi A, Zimmer L (2016) Agonist and antagonist bind differently to 5-HT 1A receptors during Alzheimer's disease: A post-mortem study with PET radiopharmaceuticals. Neuropharmacology $\mathbf{1 0 9}$, 88-95.

[34] Dubois B, Feldman HH, Jacova C, Hampel H, Molinuevo JL, Blennow K, DeKosky ST, Gauthier S, Selkoe D, Bateman R, Cappa S, Crutch S, Engelborghs S, Frisoni GB, Fox NC, Galasko D, Habert M-O, Jicha GA, Nordberg A, Pasquier F, Rabinovici G, Robert P, Rowe C, Salloway S, Sarazin M, Epelbaum S, de Souza LC, Vellas B, Visser PJ, Schneider L, Stern Y, Scheltens P, Cummings JL (2014) Advancing research diagnostic criteria for Alzheimer's disease: the IWG-2 criteria. Lancet Neurol 13, 614-629.
[35] Lowe VJ, Peller PJ, Weigand SD, Montoya Quintero C, Tosakulwong N, Vemuri P, Senjem ML, Jordan L, Jack CR, Knopman D, Petersen RC (2013) Application of the National Institute on Aging-Alzheimer's Association AD criteria to ADNI. Neurology 80, 2130-2137.

[36] Petersen RC, Aisen P, Boeve BF, Geda YE, Ivnik RJ, Knopman DS, Mielke M, Pankratz VS, Roberts R, Rocca WA, Weigand S, Weiner M, Wiste H, Jack CR (2013) Mild cognitive impairment due to Alzheimer disease in the community. Ann Neurol 74, 199-208.

[37] Prestia A, Caroli A, Wade SK, van der Flier WM, Ossenkoppele R, Van Berckel B, Barkhof F, Teunissen CE, Wall A, Carter SF, Schöll M, Choo IH, Nordberg A, Scheltens P, Frisoni GB (2015) Prediction of AD dementia by biomarkers following the NIA-AA and IWG diagnostic criteria in MCI patients from three European memory clinics. Alzheimers Dement 11, 1191-1201.

[38] Montine TJ, Larson EB (2009) Late-life dementias: does this unyielding global challenge require a broader view? JAMA 302, 2593-2594.

[39] Desikan RS, Cabral HJ, Hess CP, Dillon WP, Glastonbury CM, Weiner MW, Schmansky NJ, Greve DN, Salat DH, Buckner RL, Fischl B, Alzheimer's Disease Neuroimaging Initiative (2009) Automated MRI measures identify individuals with mild cognitive impairment and Alzheimer's disease. Brain 132, 2048-2057.

[40] Jagust WJ, Landau SM, Shaw LM, Trojanowski JQ, Koeppe RA, Reiman EM, Foster NL, Petersen RC, Weiner MW, Price JC, Mathis CA, Alzheimer's Disease Neuroimaging Initiative (2009) Relationships between biomarkers in aging and dementia. Neurology 73, 1193-1199.

[41] Braak H, Braak E (1997) Frequency of stages of Alzheimerrelated lesions in different age categories. Neurobiol Aging 18, 351-357.

[42] Tsai SJ, Liu HC, Liu TY, Wang YC, Hong CJ (1999) Association analysis of the 5-HT6 receptor polymorphism C267T in Alzheimer's disease. Neurosci Lett 276, 138-139.

[43] Kan R, Wang B, Zhang C, Yang Z, Ji S, Lu Z, Zheng C, Jin F, Wang L (2004) Association of the HTR6 polymorphism C267T with late-onset Alzheimer's disease in Chinese. Neurosci Lett 372, 27-29.

[44] Alvarez-Alvarez M, Galdos L, Fernández-Martínez M, Gómez-Busto F, García-Centeno V, Arias-Arias C, Sánchez-Salazar C, Rodríguez-Martínez AB, Zarranz JJ, de Pancorbo MM (2003) 5-Hydroxytryptamine 6 receptor (5HT6) receptor and apolipoprotein E (ApoE) polymorphisms in patients with Alzheimer's disease in the Basque Country. Neurosci Lett 339, 85-87.

[45] Lorke DE, Lu G, Cho E, Yew DT (2006) Serotonin 5-HT2A and 5-HT6 receptors in the prefrontal cortex of Alzheimer and normal aging patients. BMC Neurosci 7, 36 .

[46] Barnes NM, Sharp T (1999) A review of central 5HT receptors and their function. Neuropharmacology $\mathbf{3 8}$, 1083-1152.

[47] Filip M, Bader M (2009) Overview on 5-HT receptors and their role in physiology and pathology of the central nervous system. Pharmacol Rep PR 61, 761-777.

[48] Salmon DP, Bondi MW (2009) Neuropsychological assessment of dementia. Annu Rev Psychol 60, 257-282.

[49] de Jong LW, Ferrarini L, van der Grond J, Milles JR, Reiber JHC, Westendorp RGJ, Bollen ELEM, Middelkoop HAM, van Buchem MA (2011) Shape abnormalities of the striatum in Alzheimer's disease. J Alzheimers Dis 23, 49-59.

[50] Ramirez MJ, Lai MKP, Tordera RM, Francis PT (2014) Serotonergic therapies for cognitive symptoms in 
Alzheimer's disease: rationale and current status. Drugs 74, 729-736.

[51] Riemer C, Borroni E, Levet-Trafit B, Martin JR, Poli S, Porter RHP, Bös M (2003) Influence of the 5-HT6 receptor on acetylcholine release in the cortex: pharmacological characterization of 4-(2-bromo-6-pyrrolidin-1-ylpyridine4-sulfonyl)phenylamine, a potent and selective 5-HT6 receptor antagonist. J Med Chem 46, 1273-1276.
[52] Maher-Edwards G, Dixon R, Hunter J, Gold M, Hopton G, Jacobs G, Hunter J, Williams P (2011) SB-742457 and donepezil in Alzheimer disease: a randomized, placebo-controlled study. Int $J$ Geriatr Psychiatry 26, 536-544.

[53] Andrews M, Tousi B, Sabbagh MN (2018) 5HT6 antagonists in the treatment of Alzheimer's dementia: current progress. Neurol Ther 7, 51-58. 